\title{
The Politics of Seed in Africa's Green Revolution: Alternative Narratives and Competing Pathways
}

\author{
lan Scoones and John Thompson
}

\begin{abstract}
As calls for a 'Uniquely African Green Revolution' gain momentum, a focus on seeds and seed systems is rising up the agricultural policy agenda. Much of the debate stresses the technological or market dimensions, with substantial investments being made in seed improvement and the development of both public and private sector delivery systems. But this misses out the political economy of policy processes behind this agenda: who wins, who loses, and whose interests are being served? Drawing on lessons from country case studies from Ethiopia, Ghana, Kenya, Malawi and Zimbabwe, as well as insights from a set of complementary studies of cross-cutting themes, this article assesses the evolution of seed system research and development programmes and processes across the region. By examining how the contrasting politics and different configurations of interests affect the way cereal seed systems operate, it highlights opportunities for reshaping the terms of the debate and opening up alternative pathways to more sustainable and socially just seed systems.
\end{abstract}

\section{Introduction}

Efforts to launch a new Green Revolution in subSaharan Africa have been much heralded in policy and scientific circles in recent years. Significant amounts of international research and development (R\&D) assistance have been channelled into technical, financial and institutional support for crop breeding, market development and input subsidies in an attempt to kick-start agricultural growth based on smallholder production across the continent. The hope is to replicate the successes of the Asian Green Revolution of the 1960s and 1970s, based on the promotion of new seeds and fertilisers and, to a lesser degree, on improved irrigation and infrastructure (Evenson and Gollin 2003). Today the emphasis combines the old technological focus with a new zeal for marketbased solutions with the aim of delivering the Green Revolution through networks of local entrepreneurs, typified by the rural stockist or agro-dealer.

There is no question that boosting agricultural production in sub-Saharan Africa is needed urgently. Agriculture contributes around 25 per cent of GDP in Africa and provides jobs for some 70 per cent of the labour force, as well as a livelihood for more than 65 per cent of the population. Yet over three-quarters of Africa's poor people live in rural areas, and the proportion is barely declining, despite increasing urbanisation. Furthermore, more than 60 per cent of the rural population lives on less than US $\$ 1.25$ a day, and almost 90 per cent lives on less than US\$2/day (IFAD 2011; Livingston et al. 2011). In addition, the region's population is projected to more than double from about 796 million in 2005 to 1.8 billion by 2050 (United Nations 2004). Furthermore, land holdings have consistently shrunk in size as the population has grown. Today, the bulk of sub-Saharan Africa's 33 million small farms are both physically small - of less than two hectares of good arable land, or its equivalent - and operated at the household level using mainly family labour (Wiggins 2009; Jayne, Mather and Mghenyi 2010). At the same time, the record of agricultural growth since the early 1960 s is poor. By 2005, the continent as a whole was producing just under three times more than it did in the early 1960s: less than the rate of population growth, so that per capita production 
had fallen (Abdulai, Barrett and Hazel 2004).

But this grim statistic masks important variations through time and space. Agricultural growth slumped in the 1970 s, but in most subregions and countries this was followed by recovery and a marked acceleration of agricultural growth in the early 1980s. Hence the record for the early 1980s to the mid-2000s shows a doubling of production in some places, outstripping population growth in that period by 10 per cent, although this bulk of output comes from small farms in West Africa (e.g. Burkina Faso, Ghana, Niger and Mali) (Wiggins 2009). The dominance of smallholder agriculture means that agricultural growth and poverty reduction prospects will be closely linked with the successful transformation of this sector (Wiggins, Kirsten and Liambi 2010).

Crop output in Africa has been increasing, but this is largely driven by the expansion of cultivated land rather than productivity gains. Between 1990 and 2006 the area under cultivation increased by more than 10 per cent annually, while cereal yields over the same period were largely stagnant. The average yields of grain crops in sub-Saharan Africa have stayed below $1 \mathrm{t} /$ ha since the $1960 \mathrm{~s}$, compared with average cereal yields of $2.5 \mathrm{t} / \mathrm{ha}$ in South Asia and $4.5 \mathrm{t} / \mathrm{ha}$ in East Asia (Hunt 2011). Fertiliser use by smallholder farmers has remained at very low levels of about $8-10 \mathrm{~kg}$ of nitrogen per hectare (Morris et al. 2007). Today, fertiliser prices are double their levels in 2006 and Africa accounts for less than 3 per cent of global fertiliser consumption (FAO 2011). Moreover, the use of synthetic fertilisers by smallholders to improve production is often not economically feasible, due to high prices and the risk of drought stress. The uncertainty of obtaining higher crop yields is further worsened by the prevailing erratic weather patterns and increasing climate variability (Ingram et al. 2010). Current projections are that higher temperatures and lower rainfall in parts of Africa, combined with a doubling of the population, will lead to a 43 per cent increase in food insecurity and induce a 60 per cent increase in food aid expenditures during the next two decades (Funk and Brown 2009). Producing more food for a growing population in the coming decades, while at the same time combating poverty and hunger, is therefore a huge challenge facing African agriculture.
Proponents of the standard prescription to this food security challenge argue that, while we need to think comprehensively about what a Green Revolution for Africa would look like, the primary emphasis should be on delivering new technologies to farmers to drive agricultural development (Juma 2011; Otsuka and Kajima 2011; Ejeta 2010; World Bank 2007). It is assumed that once technology is made available, constraints on adoption and diffusion can be identified and addressed strategically, giving priority to the best endowed lands and the potentially most successful crops, such as rice and maize (Hunt 2011; Mosley 2002).

A range of major initiatives, including the Alliance for a Green Revolution in Africa (AGRA), the Millennium Villages Programme (MVP) and the US Government's new Feed the Future program, are all focusing on different elements of this agenda. Under the umbrella of the Comprehensive Africa Agriculture Development Programme (CAADP), a programme of the Africa Union's New Partnership for Africa's Development (NEPAD), national governments are signing up to 'compacts' with the aim of channelling further funds in the support of the agricultural sector. ${ }^{1}$ Broadly speaking, these initiatives share a theory of change that may be described as 'market led technology adoption' (Toenniessen et al. 2008; see also Denning et al. 2009; Sanchez et al. 2009) and which has three essential components:

1 To help farmers realise a higher proportion of their potential yield by planting new varieties of Africa's staple food crops that significantly reduce losses and increase the stability of yields while meeting human nutritional needs and consumer preferences.

2 To help farmers increase the yield potential of their fields by enhancing agricultural productivity through increasing use of synthetic fertilisers and soil management practices to supply adequate plant nutrients.

3 To build and make more equitable both the input markets that can deliver better seeds, small fertiliser packets, and other inputs to farmers, and the output markets that enable farmers to convert surplus production into profits and to generate greater income. 


\section{The politics of innovation in African agricultural systems}

Not surprisingly, given this orientation, much of the focus of the current debate, and the framing of many of these initiatives, is on overcoming narrowly defined technical and market challenges. These are of course very real and should not be underestimated. But much less discussed, and sometimes almost completely forgotten, are the political, institutional and social dimensions of designing and implementing a new Green Revolution for Africa. As Djurfeldt, et al. (2006) observe:

[T] he problem with African food production is neither technology (i.e. wrong crops) nor nature (i.e. poor soils and erratic rainfall). Nor [is it] that African governments have been reluctant to engage with the agricultural sector. On the contrary, there have been repeated attempts at ... [agricultural] intensification. Nevertheless, during the last decades attempts to implement Green Revolutions in sub-Saharan Africa have seen short-lived spurts of production rather than lasting improvements in productivity. Instead of asking, 'Why have Green Revolutions been absent in Africa?', we need to ask 'Why have Green Revolutions not been sustained in Africa?

This IDS Bulletin, with its central emphasis on cereal seed systems, focuses on the underaddressed political-economic dimensions that have hindered the emergence and spread of lasting improvements in agricultural productivity. It examines how the new Green Revolution in Africa is unfolding in Ethiopia, Ghana, Kenya, Malawi and Zimbabwe, highlighting both the diversity of experiences and the common challenges and pitfalls. Moving beyond the generic hype of much policy discussion, the articles in this collection draw out historical lessons, as well as contemporary experiences from the field.

Debates about agricultural innovation in Africa are open to a variety of competing narratives about key science and technology problems and their potential solutions, each suggesting different pathways to reach more sustainable and productive agricultural futures (Thompson and Scoones 2009). These narratives - or storylines - are promoted by particular actors in specific contexts (some with more power and influence and some with significantly less) and embody different framings, values and goals. But questions remain as to why certain narratives and pathways come to dominate debates in African agricultural policy circles while others remain marginal or even hidden from view (Keeley and Scoones 2003). In addition, which pathways are pursued and which are not is in large part a question of the governance of technology: a politics of narratives and pathways shaped by power relations and institutional interests (Scoones 2005; Leach et al. 2010; STEPS 2010; Millstone and Thompson 2010).

\section{The seeds of debate in Africa's Green Revolution}

This IDS Bulletin builds on a collaborative research project carried out during 2009-11 under the auspices of the Future Agricultures Consortium, a partnership of African and UK researchers working on African agricultural policy issues. ${ }^{2}$ This work involved researchers in five distinct country contexts and a network of other specialists engaged in more cross-cutting explorations of African seed systems. The evolution of seed research and development programmes and processes has varied greatly across these countries. In each case, a unique set of public and private actors and interests has been involved in defining priorities in seed policy and implementing projects, each seeking to influence those agendas to their advantage. Moreover, each country has a different reliance on 'modern' hybrid (or sometimes geneticallymodified) varieties and associated R\&D and supply systems and an independent informal sector, involving networks of farmer experimenters and seed bulkers and suppliers, with varying degrees of research and organisational capacity.

Seeds - and most particularly cereal seeds which provide the staple crops for the continent - as the central technological component of the new Green Revolution, are a good focus. Concerns about rising food prices - or at least high, if temporary, price volatility - and food shortages have set the stage for an intense and highly political debate about agri-food systems in recent years. These political and policy concerns come on the back of renewed interest in agricultural development, especially in Africa, after decades of neglect. The 2008 World Development Report on 
Agriculture for Development (World Bank 2007) and the International Assessment of Agricultural Knowledge, Science and Technology for Development (IAASTD) (2008) both, in rather different ways, highlighted the importance of agriculture and the boosting of production. So too did the recent UK Foresight (2011) report, The Future of Food and Farming, which warned of the prospect of catastrophic disasters created by interacting factors creating a 'perfect storm' if urgent action is not taken to put the food and agriculture system right. This growing clamour for increasing food production and security in Africa at a time of rising price and climate uncertainty has been reinforced by a long string of recent commitments made at a succession of regional and international meetings on African agriculture, with presidents and prime ministers adding their weight to calls for new investments in agricultural R\&D. 'Something must be done, and urgently', they say. But what? How? And with what consequences? A more forensic look at a cross-section of experiences from the field may help illuminate the challenges and opportunities for the way forward.

This IDS Bulletin takes one element of this much bigger debate - the future of cereal seed systems in Africa - and examines some of the challenges, dilemmas, prospects and possibilities for the future, deploying an explicitly critical analytical lens to look at the political economy of seed systems in Africa's Green Revolution. We ask, among other things: 'What interests frame the dominant narratives driving this policy agenda? What alternatives are excluded as a consequence? Who gains and who loses? And what processes of agrarian change are promoted as a result?'

New Green Revolution efforts are being played out in a post-Washington Consensus context, where alliances between the state, the private sector and privately-funded NGOs are struck in order to conduct seed research, develop products and market them. This creates a particular political economy of national seed systems in Africa, where interests and power relations are often obscured. Such alliances may be in the form of the much talked about formalised 'public-private partnerships' or 'brokering arrangements' whereby public funds - whether from national exchequers, from international aid or philanthropic support - are invested in the private sector (or non-governmental intermediaries) in order to incentivise private sector activity in favour of public policy aims. Other alliances may be less structured, including donor- or NGO-supported projects and government support programmes (such as input subsidies). Thus, overall, it is at the blurred intersection between public and private realms where the action - and associated politics - lies.

At the centre of the new vision for African agriculture is the support of a vibrant private sector, providing advice and products through agro-dealer networks. These independent, smallscale, private entrepreneurs are supposed to deliver the Green Revolution through the widespread supply of seeds and fertiliser, either on a pure commercial basis or through subsidised programmes (of a variety of sorts, including voucher schemes, direct subsidy, support to businesses etc.). In this vision, farmers are constructed as intelligent and discerning 'customers' or 'consumers', able to engage actively in markets and, with the right provision, adopt new seed varieties to improve their productivity. The focus on hybrid or improved, open pollinated varieties (OPV) of seed envisages a process of adoption of new high yielding varieties that is sustained over time and supported by a commercially-viable agro-dealer network linked to private seed houses.

However, as the country cases in this IDS Bulletin show, while the overall Green Revolution narrative is clear and broadly consistent across different actors, both public and private, the way this plays out varies significantly, depending on both the form and design of the programme (the type of subsidy arrangement, for example, or the actors involved in implementation) and, most critically, the wider political economic context of the country concerned. Moreover, while there has been substantial reflection on programme design, the influence of political-economic context has been less studied. To understand potentials and limits of the new Green Revolution agenda, this must be brought into the picture.

For example, in Africa, the research and development focus remains overwhelmingly on improved maize and on varieties where yield reductions are significant with re-use. The 'maize model' has a long history in Africa ( $c f$. Smale et al. 2011; McCann 2005; Morris 1998; 
Byerlee and Eicher 1997; Miracle 1966) and continues to dominate much of the current R\&D agenda in the region (Thompson et al.

forthcoming; 2010; Brooks, et al. 2009). The focus too is on the higher potential areas: the 'breadbasket' areas with better-endowed biophysical conditions and good market access, and richer (often male) farmers with cash to purchase inputs. There is also of course a recognition that basic biophysical constraints are a challenge, and work on drought tolerance - for example through programmes such as the Bill \& Melinda Gates Foundation-funded Drought Tolerant Maize for Africa (DTMA) and Water Efficient Maize for Africa (WEMA) - is given high priority, as well as research on nutrient use efficiency and pest resistance (notably through genetic modification, using the Bt (Bacillus thuringensis) gene.

The contribution by John Lynam to this IDS Bulletin documents the changing patterns of public investment in agriculture and seedrelated R\&D in particular in sub-Saharan Africa. He shows how these investments have been susceptible to capricious and sometimes contradictory shifts in donor priorities, with a range of unintended consequences. The changing investment patterns and priorities affect the performance of seed research and associated programmes by reinforcing the sometimes problematic division of labour between the international agricultural research centres (IARCs) of the Consultative Group on International Agricultural Research (GGIAR) and the breeding programmes of National Agricultural Research Institutes (NARIs). But of course this investment is overshadowed by that committed by the private sector, driven by different commercial interests.

Globally, as Geoff Tansey highlights, the interplay between state and private interests vying to influence the direction of agricultural technology change and use is at the heart of the contention over the future control of Africa's food system. For obvious reasons, proprietary technologies, both seeds and other products, where profits can be made dominate the $R \& D$ strategies of the private sector. As a result, what becomes available to farmers in a particular place will be highly dependent on the likely returns and the opportunities for sale by private seed companies. It is no surprise therefore that hybrid maize has come to dominate in many countries. This is not necessarily a bad thing as higher yields of an important staple food crop are critical, but it does mean that other important opportunities for innovation and diversification may be missed. Moreover, with the decline in public sector capacities documented across the country case studies in this IDS Bulletin, even with the increased support by donors and philanthropic organisations, it means that the political economy of research and development priority setting is dominated less by broad public good concerns, but more by where the resources are to prop up failing public systems.

A central theme running through all country case studies is the importance of an alliance between the state and the private sector - often through public-private partnerships (PPPs) with a central role for NGOs in implementing projects on the ground. ${ }^{3}$ The configuration of these PPPs varies, but the strong commitment to promoting an agribusiness-oriented, privatesector led model is widely evident - even if upset by rushed emergency programmes (as in Zimbabwe) or interventions which are highly contained and managed by the state (as in Ethiopia). Such alliances or partnerships are portrayed as benign, 'win-win' collaborations, with the state, the private sector and NGOs taking their respective roles in line with their own comparative advantages. Kick-starting with external finance is supposed to result, in the end, in sustained, long-term gains, with smallholders benefiting through improved productivity, poverty reduction and food security, while the private sector provides a valuable service and remains commercially viable. The state in turn provides a limited array of 'public goods', including some breeding capacity (supplying germplasm to private sector actors) and a regulatory system (seed certification, biosafety regulation) that, overall, facilitates the emergence of a strong agribusiness sector.

This 'win-win' vision for the Green Revolution is at the core of most donor and government policies, either implicitly or explicitly. It is central to the agenda represented in the 2008 World Development Report, which asserted:

An emerging vision of agriculture for development redefines the roles of producers, the private sector, and the state. Production is 
mainly by smallholders, who often remain the most efficient producers, in particular when supported by their organizations... The private sector drives the organization of value chains that bring the market to smallholders and commercial farms. The state - through enhanced capacity and new forms of governance - corrects market failures, regulates competition, and engages strategically in public-private partnerships to promote competitiveness in the agribusiness sector and support the greater inclusion of smallholders and rural workers. In this emerging vision, agriculture assumes a prominent role in the development agenda (World Bank 2007). ${ }^{4}$

It is also echoed in numerous policy documents and commentaries from AGRA, CAADP, Food and Agriculture Organisation (FAO), International Fund for Agricultural Development (IFAD), United States Agency for International Development (USAID) and others.

Despite their promise, PPPs for agricultural technology development have often been slow to deliver results on the ground because of high transaction costs in negotiating intellectual property agreements, asymmetric information on asset positions and bargaining chips, clashes of public and private cultures and a lack of mutual trust, resulting in coordination failures across actors (cf. Tansey, this issue; Spielman, Hartwich and von Grebmer 2009). Moreover, those international agencies that still claim a 'public' mandate, such as AGRA and the CGIAR, are, according to the NGO GRAIN, increasingly becoming:

public-private coalitions with direct ties to the multinationals. Their research programmes feed into the corporations' growth strategies and they increasingly adopt elements of the same companies' business models. So any talk of seeds today, if it is not specifically about local or farmer' seeds, implies private seeds - seeds that farmers have to buy and that come with tight restrictions on their use (GRAIN 2008).

The most recent moniker used to sum up the conventional wisdom on Africa's Green Revolution is the slippery term 'sustainable intensification'. This concept was developed in the context of a Royal Society (2009) report,
Reaping the Benefits: Science and the Sustainable Intensification of Global Agriculture and promoted most intensively by the UK Foresight report, The Future of Food and Farming: Challenges and Choices for Global Sustainability (Foresight 2011). Here the circle seems to have been squared. The arguments for intensification, so often dominated by high input and unsustainable options, has been combined at last with sustainability, so often associated with low input and low productivity agriculture in the past. This is yet another example of a 'win-win' narrative, of having your cake and eating it.

Everyone, it seems, agrees. From diverse perspectives, and involving droves of policy experts - 400 claimed for the IAASTD (2009) and another 400 for the UK Foresight report (2011) to start with - a consensus appears to have been brokered. Feeding the world - or feeding Africa is possible with a neat combination of technological innovation and market discipline, with public-private partnerships built across diverse state and non-state actors ( $c f$. Godfray et al. 2009). But of course people don't agree. The consensus, if there is one, is superficial and therefore very fragile. As so often is the case in apparently technical discussions led by accredited experts in elite institutional settings coordinated by prestigious organisations, the politics get obscured and, consequently, the underlying tussles over framings, interests, and distributional outcomes become overwhelmed by the focus on technical options and simplistic economic arguments (Scoones 2009). The technical fix, often translated into an institutional fix through large programmes, 'grand challenges' and implementing compacts thus dominates, and the wider debates about future options, centred on values, competing visions and politics gets subsumed. This is not a new story for African agriculture - see the 2005 IDS Bulletin on 'New Directions for African Agriculture’ (Vol 36 No 2) for an extensive discussion - or any other policy area for that matter; but as attention and money gets focused yet again on the 'African problem' and careers are built and reputations generated, the stakes become higher.

The seemingly benign consensus of the 'win-win' dynamic at the centre of the new Green Revolution can be challenged on a number of counts. Any scratching beneath the surface reveals some important power dynamics and 


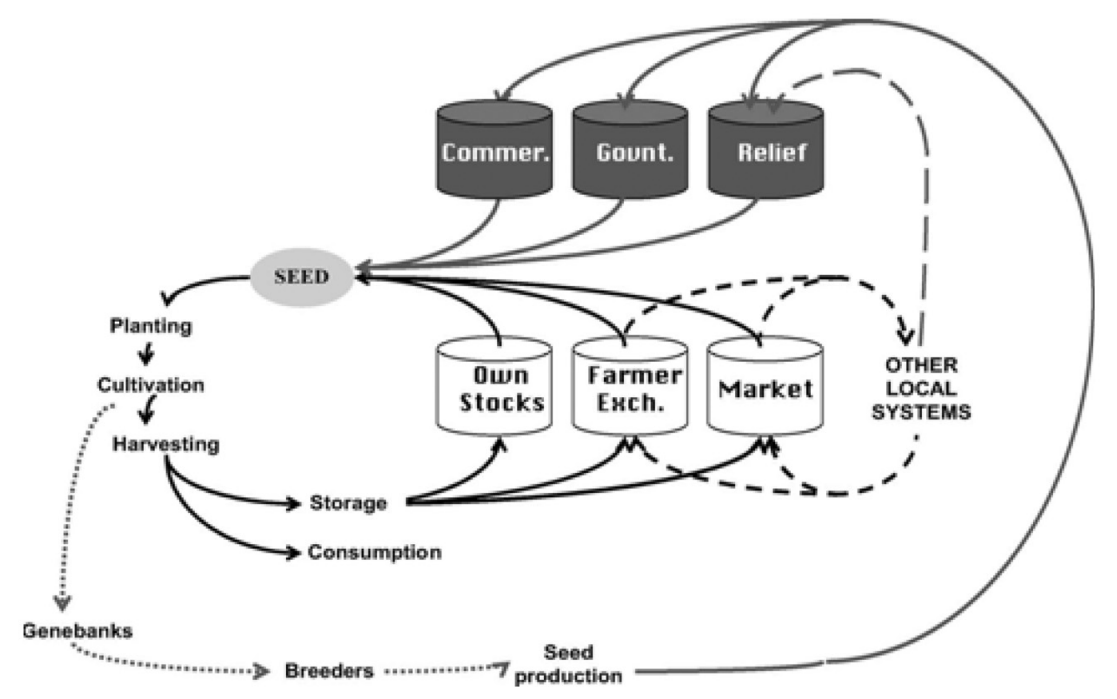

Source Adapted from Almekinders and Louwaars (1999), in Sperling, Cooper and Remington (2008).

contested politics. There are inevitably winners and losers, and alliances and partnerships, despite the rhetoric, are never constructed on an even playing field. And in the process, networks, institutions and wider agrarian politics are reconfigured. This political process therefore defines particular pathways for the future, while blocking others. Whether intentional or not, the result is the shaping of particular agrarian futures in ways that have important politicaleconomic implications. Unpacking the process by which this shaping of future options occurs and the interests involved in that process is an important part of the focus of this IDS Bulletin. The intention is not simply to be critical of current programmes, although this is sometimes needed, but also to open up the debate, to expose alternative pathways and options and have a more robust discussion about future trajectories. Currently such debate is constrained by a narrow and technocratically-defined framing, where the politics of the new Green Revolution is obscured by either a deluge of technical imperatives or a sense of urgency that suggests deliberation on alternatives is a wasteful indulgence.

\section{Seed system politics}

There has been much important work on African seed systems, ranging from studies of agricultural science and technology development (InterAcademy Council 2004), seed research and development (Minot et al. 2007; De Vries and
Toenniessen 2001), seed marketing systems (Crawford et al. 2003; Morris 1998), local seed systems (Almekinders et al. 1994; de Boef et al. 1993); seed policy (Rohrbach et al. 2003; Tripp 2001; 2000; 1997; Wiggins and Cromwell 1995; Cromwell et al. 1992) and seeds in the context of humanitarian aid (Sperling et al. 2009; 2008; 2004; McGuire and Sperling 2008; Sperling 2008).

Seed systems can be characterised in terms of the interaction of different elements. Figure 1 depicts the formal and informal seed systems, their component channels and how these are linked (Sperling et al. 2008; Almekinders and Louwaars 1999). The dark cylinders represent 'formal' seed sources, where bred seed is distinct from 'grain' and where the system includes formal breeding, gene banks, commercial companies, agro-dealers and others. The formal sources are distinguished from the light 'informal' sources, where seeds are selected from home farm production and saved, and the system includes household seed selection and saving, farmer networks of gift and exchange and local markets. Also highlighted is a significant third category, 'seed aid', delivered through humanitarian efforts as part of post-conflict recovery and emergency programmes (McGuire and Sperling 2008; Sperling 2008).

There are many flows between the formal and informal systems. For example, new 'modern' 
varieties of seed, though launched by the formal system, may move into informal channels quickly and may be recycled by farmers, disseminated through farmer-to-farmer networks or even sold in local markets. At the same time, local varieties, or landraces, may be brought into the formal system for testing, certification and multiplication and then released officially through conventional channels. Figure 1 also shows the special importance of local seed or grain markets. These markets are vital for farmers to meet their seed needs, especially for poor farmers and in difficult times. For many farmers, local markets are a good source, after home stocks, as they may sell the same varieties as farmers routinely sow and at reasonable prices.

Thus, a 'seed system' is the sum of physical, organisational and institutional components, their actions and interactions that determine seed supply and use, in quantitative and qualitative terms, and include formal, informal and seed aid elements. In Africa, seed supply is dominated by informal systems - in some estimates around 80-90 per cent (Almekinders and Louwaars 1999). This varies by crop, of course, with the cereals and particularly maize, where hybrids now represent an estimated 44 per cent of maize area in East and Southern Africa (outside South Africa) and 60 per cent of maize area in West and Central Africa, being supplied more through formal systems, although often only sporadically and inconsistently, depending on seed supply capacities, private sector development and market linkages (Smale et al. 2011). Relief seed, especially in Africa, has increased significantly since the 1990s, and in some years is delivered each year and may be the major component of seed supply in some countries.

Overall 'seed security' thus arises from the combination of seed availability, access and quality (Remington et al. 2002). This is dependent on the functioning of the seed system, and its ability to deliver all three of these key functions. Green Revolution efforts focus primarily on the formal system - on seed quality (increasing yield levels through breeding, and in some cases genetic engineering), combined with issues of seed availability and access, through the focus on private sector development, the facilitation of market channels and the support of agro-dealers. Through an improvement of the formal system, with spin-off benefits through the provision of new genetic material to the relief and informal systems, the technological innovations of the Green Revolution are to be delivered.

Yet this delivery of new technologies presupposes a particular structure and function of the existing seed system, whereby strengthening of the formal system is all that is required. It is often thought that informal systems are inefficient and supply only low quality seed in variable quantities. Many assume that availability and quality are severely constrained and therefore urgent intervention is warranted. This is often the premise of relief and recovery programmes for example. But informal systems have been shown to be remarkably resilient (Almekinders and Louwaars 2002, 1999), offering high levels of genetic diversity and the ability to adapt to changing circumstances through local innovation systems (Richards $e t$ al. 2009; Richards 1989, 1986). It is often assumed that poor harvests mean lack of seed availability, but this is often not the case and seed supply persists even following sustained periods of drought or conflict which disrupt food production (Sperling 2008; Sperling et al. 2004; Sperling and Longley 2002). As many contributions to this IDS Bulletin note, recognising the importance and potentials of informal systems is essential to Africa's agricultural future and a narrow focus on the formal system to drive a new Green Revolution in the region may mean missing out on the largest, most vibrant area of technological development and potential transformation. For informal systems, while resilient and productive in many respects, are not perfect and there are major opportunities for improvement through innovation which, as Jacob van Etten explains, links local systems with cutting-edge science and technology in new ways.

Yet most discussion of the Green Revolution, whether concentrating on the formal seed system or more rarely on the informal system, focuses on the technical elements: breeding, regulation, marketing and so on. As noted above, all of these are of course important factors in shaping the overall performance of the total seed system. But what is often missing is an analysis of the politics that influences both the understanding and the functioning of the seed system.

Politics affects the framing of the system, influencing what elements are given priority over 
others, where investments are channelled, what institutional arrangements have the power to govern seed policy and practice, and how the overall narrative of system objectives is constructed. Politics also affects the interactions between these elements. Thus the cylinders and the arrows in Figure 1 are all constituted through political relations. How big a particular element is and how it relates to others depends in large part on the political economy of the setting. These dimensions are however often not highlighted in the literature and frequently discussed only in superficial ways in discussions of seed policy.

To get at these seed system politics, the Future Agricultures Consortium undertook a broad mapping of the national seed systems in five countries. This involved examining the historical origins, key narratives (defining key seed policy problems and solutions), actors and networks (the individuals and organisations involved and their connections) and political interests (the power relations) that push particular perspectives above others, define winners and losers in the policy process and shape particular socio-technical innovation pathways. The lessons emerging from those analyses comprise the core of this issue.

\section{Lessons from country studies}

This IDS Bulletin is structured around case studies of seed systems in Ethiopia (Dawit Alemu), Kenya (Hannington Odame and Elijah Muange), Malawi (Blessings Chinsinga), Ghana (Kojo Sebastian Amanor) and Zimbabwe (Charity Mutonodzo-Davies and Douglas Magunda). These are set in context by a series of overarching papers - on the history of cereal seed development (James C. McCann), on African seed systems and donor policy (John Lynam), and new approaches to innovation in informal seed systems (Jacob van Etten). The IDS Bulletin concludes with a paper reflecting on the global politics of seed systems, setting the Africa-specific discussions in a wider context (Geoff Tansey).

The papers, in different ways in different contexts, ask a series of questions:

- Are the emerging alliances at the heart of the new Green Revolution, backed by international aid and philanthropic funding, opening up opportunities for particular (multinational) agribusinesses with clout and influence, and so undermining others?

- Is the dominance of certain players in subsidy programmes providing a platform for market dominance in the future and the introduction of products - including genetically-modified crops - by stealth?

- What forms of patronage - linking state officials and private/NGO players - are emerging on the back of subsidy programmes? Who is excluded as a result?

- Is this really rooted in support for a freemarket private sector, based on small-scale entrepreneurs serving poor and marginalised farmers, or simply support for elites (including foreign capital)?

- Which small-scale entrepreneurs can operate under these conditions? Who are the new entrant entrepreneurs, in social, political, ethnic terms? How is this redefining these rural economic relations and to whose benefit?

- Who are the losers from the new Green Revolution - what products, which people and what institutions are missed out, and lose support - or worse, are undermined by these processes?

The focus on cereal seed systems allowed the Future Agricultures team to concentrate on a similar set of crops with a key influence on food security at household and national levels across five countries. As the contributions show, whether grown for local subsistence or traded commercially, the significance of cereal crops to national politics (and therefore arguments about food security and sovereignty), commercial interests and local livelihoods is profound.

The five country cases reported here offer insights from a wide range of political economic and agro-ecological contexts. Some countries, such as Kenya, have a strong and growing private sector, with a long history of providing modern agricultural technologies to farmers. Others, such as Ethiopia and Malawi, have relatively nascent private sectors and a long history of state intervention in the seed system. By contrast, Zimbabwe provides an example of a once vibrant seed system only now emerging from a decade of political and economic turmoil, which has been exacerbated by seed relief programmes implemented by the government and aid agencies which bypassed the normal market chain. 
Table 1 Characteristics of the maize seed system in East and Southern Africa

\begin{tabular}{|c|c|c|c|c|}
\hline & Ethiopia & Kenya & Malawi & Zimbabue \\
\hline Maize area - 1990-2007 ave & $1.7 \mathrm{~m}$ ha & $1.6 \mathrm{~m}$ ha & $1.4 \mathrm{~m}$ ha & $1.4 \mathrm{~m}$ ha \\
\hline $\begin{array}{l}\text { Improved maize adoption as } \\
\text { per cent of area - } 2007 \text { (1997) }\end{array}$ & $19(8) \%$ & $72(21) \%$ & $22(14) \%$ & $80(22) \%$ \\
\hline $\begin{array}{l}\text { Improved maize seed sales } \\
\text { (OPV + hybrid) } 2007 \text { (1000 t) }\end{array}$ & $\begin{array}{l}8.2 \\
(2.0+6.2)\end{array}$ & $\begin{array}{l}28.0 \\
(1.7+26.3)\end{array}$ & $\begin{array}{l}7.9 \\
(5.4+2.5)\end{array}$ & $\begin{array}{l}28.1 \\
(2.2+25.9)\end{array}$ \\
\hline $\begin{array}{l}\text { Registered maize seed } \\
\text { companies }\end{array}$ & $\begin{array}{l}7 \text { (6 private regional, } \\
1 \text { public) }\end{array}$ & $\begin{array}{l}11 \text { (6 private national, } \\
1 \text { private regional, } \\
4 \mathrm{MNC} \text { ) }\end{array}$ & $\begin{array}{l}4 \text { (2 private national, } \\
2 \mathrm{MNC})\end{array}$ & $\begin{array}{l}9 \text { (6 private national, } \\
3 \mathrm{MNC})\end{array}$ \\
\hline $\begin{array}{l}\text { Average production of } \\
\text { seed per company (tons) }\end{array}$ & 1131 & 2545 & 1219 & 3122 \\
\hline Seed Act & N & Y & Y & Y \\
\hline Plant Variety Protection & Y & Y & N & Y \\
\hline Variety Registration & Y & Y & Y & Y \\
\hline
\end{tabular}

Source Langyintuo et al. (2008).

Table 1 offers some comparative data focusing on maize for East and Southern Africa (Langyintuo et al. 2008, 2010). Exactly comparable data was not readily available for Ghana, but this country has witnessed rapid adoption of improved varieties (nearly all OPVs) from the late 1980s, accompanied by a doubling of maize area in the last 25 years (Alene et al. 2009). By 2005, 89 per cent of maize area was planted to improved maize, while this was only 1 per cent in 1981 (Smale et al. 2011). As with Ethiopia, the presence of Sasakawa-Global 2000 helped push up adoption rates through demonstration plots especially during the 1990s. Between 1965 and 2005, 37 varieties (31 of which were OPVs) were released, with only 14 of these coming from the private sector (Alene et al. 2009). Only 8 per cent of all maize seed sales were hybrid (Tahirou et al. 2009). However no varieties were released in the period from 2002-06 (Setimela et al. 2009), reflecting the collapse of public breeding efforts and only a slow growth in the private sector seed system (Lynam et al. 2010), and only around 10 per cent of all seed was being supplied through formal channels (Tahirou et al. 2009).

In the article on Ghana, Kojo Amanor argues how a strong commitment to agribusiness development dominates policy and is reinforced by US-funded NGOs and private capital, which has resulted in a particular configuration of actors driving a narrowly defined Green
Revolution agenda. With the policy focus now dominated by a commercial, agribusiness model, there have been knock-on effects in the traditional areas of public research and extension, changing priorities and practice at regional and national levels, and reducing opportunities to promote at a more participatory, farmer-led approach. This serves a particular set of political-economic interests, whereby a close alliance between the state, local/foreign capital and business interests and donors and NGOs construct a particular vision of the future of agriculture. As a result there is no separation of policy prioritisation, investment, oversight/regulation and production. As Amanor argues, this apparently 'universalising consensus' acts to exclude alternative perspectives and practices in agriculture, suggesting that there is only one pathway to a new Green Revolution in Ghana, when of course there are - or could be many.

In Ethiopia, by contrast, Dawit Alemu shows how the state is much more present, even in so-called private sector activity. While there are contrasting interests in federal and decentralised state level activities, it is state-driven imperatives that define what private sector activity is able to happen and where. With the suppression of non-sanctioned entrepreneurial activity, much is driven underground, operating outside the formal economy. This is important, 
but it is difficult to trace its overall impact. However, centrally-directed, state supported efforts - including numerous campaigns, special projects and programmes - confront numerous blockages - in supply and distribution of seed for example - undermining efforts to extend the Green Revolution. Farmer-based seed multiplication efforts are seen as an important route to resolving this. These involve local production and local marketing, aimed at boosting production in a locality, linked to and supported by quasi-private, yet state controlled, seed enterprises. Inevitably these efforts too are bound up in a political economy which depends on the relative influence of centralised directives and regional autonomy, as well as the balance between state-directed control and private entrepreneurship.

Hannington Odame and Elijah Muange argue in their article that Kenya is in many ways the 'poster child' for Africa's new Green Revolution, and it supports several major public-private partnerships seeking to build on a strong private seed sector and a well developed and extensive network of small-scale agro-dealers to promote the spread of new agricultural technologies. They report, however, that agro-dealers are spread unevenly throughout the country and are inevitably concentrated in the higher potential agricultural areas. With funding from both philanthropic foundations and government, these small-scale rural entrepreneurs are now being provided with a range of technical support from international NGOs, including training in business management. Nevertheless, making a business out of selling seeds and fertilisers to poor farmers is risky, especially in the dryland areas where demand is low and often variable. As Odame and Muange report, links with particular seed companies are essential for the survival of these enterprises, but the changing structure of the Kenya seed industry and the entry of large multinational players is changing this dynamic. This is acting to narrow the choice of seeds and crop types for farmers in all areas. Moreover, these alliances have thus far largely ignored informal seed systems, which often serve the majority of poor farmers in more marginal areas, and therefore remain beyond the reach of new initiatives and investments.

In his contribution on Malawi, Blessings Chinsinga highlights how maize politics has come to dominate that country's particular brand of electoral politics and created a seed industry controlled by multinational companies, who offer farmers a narrow range of products. The interests of seed companies, donors and the state coincided around a set of input support programmes over the past decade, especially the Agricultural Input Subsidy Programme (AISP), which since 2005 has been providing farmers with vouchers to purchase hybrid seed and fertiliser. The AISP has contributed to Malawi's success at improving its food security situation, which has raised its profile in the international press. In reality, however, it has been an intensely political initiative, with government wrangling with donors and the private sector over the best approach. The subsidy programme is a major drain on government resources, and a significant focus for donor and NGO investments too. Moreover, the AISP has been exploited as a source of political patronage and 'capture' at different levels. Although in the last year, there has been some reduction in subsidies (e.g. to tobacco growing), the core focus on hybrid maize for food security remains. This is because the political fortunes of the government are intimately tied up with the continued support for subsidy programmes, with the previous two elections having been fought on this basis. Over time, and pushed by the donors in particular, there has been a greater incorporation of the private sector in the delivery of the programme. Global seed companies - notably Monsanto provide seed in bulk and a network of agrodealers deliver this through a voucher programme. This has proved a major boon for the major seed companies and some well connected small-scale entrepreneurs alike. The alliance between the state, the donors and the private sector (both global multinational and very local) is strong. This has excluded alternative perspectives and has had a diversity of indirect effects, including favouring certain enterprises over others (those with capital and able to link up with the large seed houses), certain seed products (hybrid/OPV maize over other seed options) and research priorities (undermining national breeding capacities).

In Zimbabwe, as part of the relief and rehabilitation programme of both government and donors/NGOs a similar dynamic exists, as described by Charity Mutonodzo-Davies and Douglas Magunda. Again, major input subsidy 
programmes have been rolled out since 2009 .

These were focused on getting improved seed to poor farmers in both communal areas and new resettlement areas. The donors provided funds through NGOs who focused on communal areas, while the government channelled funds through state agents and focused on the new resettlements. Despite differences in implementation strategy, the overall narrative justifying the interventions was the same: there was a major gap in supply of seed and in order for food security to be assured, subsidised (indeed free in most instances) improved seeds should be supplied. These efforts were deemed 'emergency' measures, and so implemented in a hurry. In most instances they bypassed existing channels for the delivery of seed and relied on those commercial suppliers who could deliver in bulk and fast. For many, the programme has acted to undermine the longer-term recovery of the seed sector, while providing support to a narrow group of commercial interests, and offering a form of patronage to state and NGO actors implementing programmes at the local level.

\section{Delivering Africa's Green Revolution}

At the centre of all new Green Revolution initiatives documented by the case studies (with the exception of Ethiopia) is the agro-dealer. In the narratives promoting Green Revolution policy positions, the agro-dealer is presented as a plucky, dynamic, individual (usually male) entrepreneur, running an independent store as a family business. Combining a service function with supplying basic commodities, and able to reach remote corners of the rural areas, supporting agro-dealer networks is seen as a way of compensating for the lack of public extension and reliable input supply systems, as well as the poor coverage of larger-scale agricultural stockists and traders. The objective is to increase the availability, affordability and access of smallholder farmers to agricultural inputs, particularly improved seeds, fertilisers, tools and crop protection products. The underlying assumption is that by serving as 'one-stop-shops' for agricultural technologies, services and advice, agro-dealers can contribute to increased awareness and help build demand for the inputs.

Significant efforts have been invested in supporting agro-dealers as part of the new Green Revolution agenda. The Gates-Rockefeller supported AGRA has committed itself to training at least 10,000 well-functioning agrodealers throughout Africa over the first five-year phase of its Agro-dealer Development Programme (ADP) (AGRA 2011). A number of NGOs are working closely with AGRA on this agenda, notably the Citizens Network for Foreign Affairs (CNFA), which operates its agrodealer programme in five African countries, including Ghana, Kenya, Malawi and Zimbabwe. Several other NGOs, including Catholic Relief Services (CRS), Netherlands Development Organisation (SNV) and CARE, as well as the International Fertilizer Development Center (IFDC), a US public international organisation, have all identified supporting agro-dealers as a key route to supplying new technologies and advice to farmers.

Assistance to agro-dealers by these programmes takes various forms, but generally includes:

- Providing business and technical training to agro-dealers so that they have the tools they need to build and maintain successful businesses and the capacity to impart valuable technical knowledge to their farmer customers.

- Facilitating access to financial services through credit guarantees that mitigate risk for banks and other financial institutions, providing matching grants to promote investment in new business start-ups, and processing and marketing ventures.

- Supporting agro-dealers to serve as output marketing hubs, providing processing and value adding services for farmers, from storage to transport to milling and packaging.

- Undertaking policy advocacy to promote the agro-dealer model at national and regional levels.

Yet beneath the simple agro-dealer narrative is of course a more complex story. While the standard narrative focuses on an individual business which is owner-operated and centred on a multi-commodity store, often selling everything from tea and sugar to seeds and fertilisers, there is a wider spectrum of businesses that fall under the broad, and rather poorly specified, agrodealer category. Some agro-dealers are rural investments with an absent, urban-based owner, with locally employed staff; others are part of a chain of stores, linked perhaps to urban supermarkets; still others are tied to a particular seed house and act as an agent for a particular 
set of products; and others are wholesalers able to operate at scale but with limited retail reach. The case studies in this IDS Bulletin indicate that variations of all these agro-dealer types operate in Ghana, Kenya, Malawi and Zimbabwe.

In Ethiopia, private entrepreneurship is more circumscribed and rural stockists and seed marketing tend to be highly controlled by the state (Spielman et al. 2009; Minot et al. 2007). A recent study on the country's seed sector has called for 'more consideration should be given to long-term policies designed to build a dynamic private sector to promote fertilizer, seed, credit, and market information systems. A greater degree of flexibility in how inputs and services are provided, and a greater degree of choice for smallholders, can open up new market and technological opportunities in the agricultural sector' (Spielman, Kelemwork and Dawit Alemu 2011). This is likely to include the emergence of new agro-dealers, as the COMESA Regional Agricultural Inputs Program (COMRAP) of the Common Market for East and Southern Africa (COMESA) recently announced the launch of a new agro-dealer development component in association with IFDC and the CFNA supported Agricultural Market Development Trust (AGMARK). The aim is to train and certify 5,800 agro-dealers across eight East and Southern African countries over 2011-12, including many in Ethiopia (IFDC 2010).

An appreciation of the diversity of agro-dealer forms is important as it affects who gets access to seed and of what type. As documented for the Zimbabwe case, relief operations which have dominated seed supply in some areas tend to favour the larger operators, particularly wholesalers who are able to deal in bulk and have an audit and accounting system compatible with donors' requirements. The result, as MutonodzoDavies and Magunda report, is that the smaller agro-dealers - the independent owner-operated stores - are sidelined, unable to stock seed and many have closed as a result of the flooding of the market, and the market dominance of the bigger players. Certain market based mechanisms for the supply of seed, such as voucher systems, similarly require the ability to cope with uncertain cash flow and claiming back funds later. This is only possible for certain businesses operating at a certain scale, and so exclude others from operating within such schemes, as Odame and Muange show in the Kenya case. In other areas, the tight relationship between stockists and particular seed suppliers is evident, reducing the range of seed choice for the producers. Large companies, such as Monsanto, Pannar and Pioneer, are able to capture the agro-dealer network with relatively small inducements, thus controlling the market without having to invest in their own seed traders, as Chinsinga highlights in the Malawi example. Some seed has a relatively high return, and is pushed by large seed houses (hybrid maize being the most obvious case), while other seeds, more available on local markets and not part of the core portfolio of the commercial operators will not be found as part of agro-dealer networks. And seed makes profit only in certain years and in certain places. Coke or biscuits may be a better business proposition in the absence of relief subsidies for many, and so in more remote areas for example seed supply may be limited, even if a notional agro-dealer is present.

Agro-dealers therefore operate in 'real markets' (cf. Hewitt de Alcántara 1993), shaped by historical, social, cultural and political factors. External interventions in support of agro-dealers may thus influence the operation of such markets significantly. We have already noted the potential distorting effects of relief aid. But public or philanthropic support of private enterprises will also influence how markets operate. Who gets access to an NGO or donor programme will be dependent on a variety of factors, including social connections and power dynamics in a local community. External interventions result in often very different market structures and forms of market power, influencing what seed is supplied to whom by whom.

Who then are these new entrepreneurs delivering the Green Revolution? As we have discussed, agro-dealerships taken on diverse forms and their owners and operators reflect this diversity. Business people in rural areas frequently have a special status and role. They are often well-connected, established members of a community, perhaps connected to local political actors; maybe the councillor or local MP. To have the assets to set up a business, however small, they must often have had a particular background. The agro-dealer owner may, for example, be a retired professional - a teacher or other civil servant living back in their home area, often with good connections outside. Such linkages may be important in getting a prime 
location in a small-scale business centre or significant in getting hooked up with a particular company, NGO or donor project. Market control may emerge from such connections through the suppression of local competition. Some new entrepreneurs are able to link different businesses - butcheries, small stores, beer halls and transport, for example. The result being an important economic - and political - force in an area: someone to be reckoned with. In some places rural entrepreneurs are 'outsiders', linked to particular ethnic groups with long histories of migration linked to business activities (e.g. Kikiyu traders in the Rift Valley of Kenya). This may lead to resentment or respect, depending on the setting and time.

Thus who gets seed, and of what type, linked to what loans and credit and what sources of advice and in what form will depend on the sociological dimensions of these market interactions. Rural business dynamics are poorly understood with very limited research having been undertaken. With the simple vision of the individual owneroperated entrepreneur operating in a free market dominating the policy narrative, such factors are simply not considered in the design of entrepreneurial support programmes. But supporting local entrepreneurial activity through 'agro-dealers' is not so simple: intervention necessarily must engage with a complex sociopolitical web.

Understanding how rural seed markets actually work, and the interactions between formal and informal, subsidised and independent elements, is therefore important as it has big implications for seed access and supply - in terms of the amounts of seed, what is stocked, what advice is given and ultimately what shape the Green Revolution takes.

\section{Seeds as relief and humanitarian aid}

Seeds have become an important part of relief and humanitarian aid in recent years, especially in Africa. For example, FAO alone implemented 400 seed relief projects between 2001 and 2003 (Sperling et al. 2008). Some countries have received seed aid every season over many seasons, in a few cases for nearly 40 years. In trying to link relief with development and recovery from conflict or disasters, the idea is to rebuild agricultural systems and provide forms of 'social protection' that are not just welfare handouts but actually allow people to get back on their feet (Remington et al. 2002; Sperling and Longley 2002). The general argument is sound, but the practice on the ground is often somewhat wanting.

Many of these programmes are designed on the assumption that there is a gap in seed availability. Seed requirements are calculated at a country level using heroic assumptions and often a very limited knowledge of informal seed supply. A series of poor harvests is usually assumed to result in seed shortages, although this actually may not be the case as seed supply is often highly resilient to shocks and stresses (Sperling 2008).

A variety of intervention approaches have been adopted by aid agencies to deliver seed in emergency and post-conflict situations. These include direct seed distribution (sometimes with tools), sourced either from commercial seed houses or from the region. Such approaches may overcome immediate seed access problems for some, but whether they contribute to longerterm recovery has been questioned in many instances (Sperling and McGuire 2010; Sperling et al. 2004; Longley et al. 2002; Sperling and Longley 2002). Where such emergency seed provision transforms into a longer-term programme with seed aid institutionalised on an annual basis the effects can be highly negative. Markets are distorted or destroyed, informal systems are disrupted and sometimes inappropriate seed is provided, undermining local genetic diversity and longer-term adaptive capacities (McGuire and Sperling 2008; Rohrbach, Mashingaidze and Mudhara 2005; Remington et al. 2002; Tripp 2001). Across the countries discussed in this IDS Bulletin seed aid has been nearly continuous in some parts of Kenya (eastern), Malawi and Zimbabwe (southern) since the early 1990s, and in Ethiopia (central/northern highlands) since 1974 (Sperling et al. 2008). Recognising the problems of direct seed distribution, market oriented approaches have become more popular in recent years. Seed vouchers, linked to seed fairs, or vouchers or cash transfers for seed purchase from agro-dealers have all been tried extensively across Africa (Rohrbach et al. 2005; Walsh et al. 2004). Such market-based approaches linked to informal systems rely on the existence of seed exchanges or fairs, often dependent on NGOs and external funds. Issues of quality of farmer- 
saved seed have also been raised. When linked to formal market systems, the spread of agrodealers and the type of seed stocked may also be highly constrained, again limiting the impact of such relief programmes, especially in poorer or more remote areas where such interventions are most needed (Sperling et al. 2008).

Given this background, can relief systems (including ones that have become 'protracted' and so institutionalised as part of development activities) kick start a Green Revolution in Africa, dealing at a stroke with post conflict and disaster rehabilitation as well as longer term growth? Are these aid delivery mechanisms the right ones for getting new technologies into farmers' hands and supporting an up-scaling of production and marketing? The experience is distinctly mixed, with much well-grounded critique of such approaches. As the case studies in this IDS Bulletin show, the impacts may be negative. As the article by Mutonodzo-Davies and Magunda shows for Zimbabwe, the seed relief undermined local markets and put agrodealers out of business at the same time. Furthermore, while the delivery systems have changed, questions remain. Sperling et al. (2008: 603) sum up this state of affairs:

The giving of repeated seed aid is detrimental - full stop. It also signals that the problem being addressed has probably been misdiagnosed... In many of the cases where seed relief is conducted, seed aid may not actually be the most appropriate response at all. Many contemporary cases of emergency are chronic cases of problems of seed access. Fundamentally, these result from poverty.

A more problem-focused approach which links context-specific limitations in the seed system to particular interventions required, and increasingly sophisticated approaches to seed security assessment have been developed to allow this to happen (cf. Sperling and McGuire 2010; Sperling et al. 2008, 2004).

So why is it, despite the growing recognition of the problems and the development of new assessment and evaluation methodologies that myths about the many benefits of seed relief continue to persist in forms that are inappropriate or detrimental? Here again a focus on the political economy of seed systems is essential. There are many vested interests in the seed relief industry. Disasters bring suffering, but they also bring money; and some organisations and businesses rely on this as their raison d'être and source of revenue. Long-term, 'protracted' disasters are of course better than one-off short term ones, so the incentives are high to create what are euphemistically dubbed 'permanent emergencies'. Over the last two decades some key players have become tightly linked in the seeddisaster-relief nexus. UN agencies such as the Food and Agriculture Organisation (FAO) and the World Food Programme (WFP) are major players, as are multinational seed companies who supply certified seed in bulk for relief operations. For such private companies a guaranteed bulk supply of a limited range of products with no marketing and distribution requirements keeps costs down and profits up.

NGOs are deeply involved in the seed aid agenda, with many transforming their operations from food handouts to supplying seeds, fertilisers and tools in an apparent shift from 'relief' to 'development'. Some have specialised in this area, such as CRS and CARE, and in some countries have maintained large operations linked to seed relief. International aid agencies supplying the funds are happy with large and regular disbursements which can be measured in easy ways (x amounts of seed delivered to $y$ people), so seed relief dovetails nicely with the increasingly stringent audit culture of the aid system. In some situations, such as Zimbabwe, where politics currently prevents engagement with the government for long-term development, 'protracted relief' and an emergency mode allows aid agencies to continue a presence through alliances with NGOs. African government agencies are also reliant on seed aid operations, often mediated through NGOs, to finance their day-to-day activities, as this is where vehicles, fuel, per diems and sometimes even salaries come from. And politicians too may get in on the act. There is nothing like a relief operation to show that the state is helping its people, or in some instances, that some of its relief aid becomes diverted to particular areas, rewarding certain political supporters and feeding patronage networks.

Thus the mutual benefits and convergent interests of these powerful actors results in strong incentives to maintain the status quo and 
spin out any emergency. As the Zimbabwe cases shows, shifts to more complex market-based solutions and away from direct distribution, for example, may be resisted on a number of fronts, while the suggestion that seed availability is perhaps not a problem is met with looks of horror and a shower of statistics that demonstrate major seed supply 'gaps'. In emergency contexts, the rush to action may overwhelm more detailed assessments of options, and their pros and cons. Yet as a large - and in recent years growing - component of African seed systems, the seed relief element cannot be ignored. In some cases, such interventions may help a push towards a new Green Revolution, but in many other instances, confusions, distortions and diversions may undermine such efforts.

\section{Alternative pathways to diverse Green Revolutions}

There are thus many political-economic factors that shape Africa's seed systems, and so potentially many pathways to a new Green Revolution for the region. These include the technological focus of breeding efforts on certain key crops and varieties through particular breeding or genetic engineering techniques, which means that other 'orphan' crops or alternative breeding strategies get short shrift, with limited funds, low prestige and inadequate R\&D. They may also include the emphasis on market solutions through alliances with the private sector and the promotion of agro-dealers which gears the Green Revolution towards certain 'breadbasket' areas with well-connected market linkages, a substantial network of smallscale commercial enterprises and high market demand for certain types of seed which are central to the marketing operations of established seed houses in the formal systems, and away from support for informal seed systems in more remote areas with limited market access. And they may also include the focus on direct seed distribution as part of seed aid and relief programmes, which link 'social protection' and humanitarian assistance with development in ways that may act to undermine local markets and seed production and sharing.

In other words, less by explicit design but more by cumulative default, political-economic interests create certain pathways for the new Green Revolution, constructing seed systems in their wake in particular ways, while obscuring or even disrupting alternatives. What then are the alternative pathways to a new Green Revolution that do not subscribe to the narrow framings and particular constructions of the mainstream versions described above? Can they perhaps deliver the same benefits, or indeed more to a wider group of people, through different means? And what are the political-economic obstacles to achieving these alternative pathways?

For example, can informal seed systems be galvanised more effectively? They are after all by far the dominant source of seed, and despite decades of effort by research and extension systems across the continent the penetration of the formal system, even in crops like maize (see Table 1) remains patchy. The mainstream Green Revolution focus by attempting to replicate a particular technical-economic success story from Asia perhaps underestimates the importance of informal systems, as responsive, adaptive and flexible systems more suited to the agroeconomic contexts of Africa. Where the importance of informal systems is recognised, the focus is often an attempt to articulate them within the formal, mainstream Green Revolution project. Too often participatory plant-breeding becomes an outsourced approach to testing varieties developed by accredited breeders, and farmer-based seed multiplication becomes a route by which farmers are co-opted into private sector projects for the multiplication and delivery of seed on a low-cost, decentralised basis. While, as Dawit Alemu shows for Ethiopia in this IDS Bulletin, such systems have great advantages, certainly over the centralised, controlled systems of seed supply in the past, they do not really offer a farmer-led source of innovation and seed supply rooted in a local seed system.

But this is not to say that all is well and that 'indigenous' systems are all that is needed. Far from it. But how can local expertise be mobilised, together with external sources of technological innovation and business skill, in new ways? Perhaps the old top down, linear model of upstream to downstream research and innovation linked to delivery through public extension and private business is inappropriate? As van Etten highlights in his contribution to this IDS Bulletin, Web 2.0 technologies allow the mobilisation of new networks of knowledge and expertise in ways unimaginable a decade ago. The extraordinarily rapid development of genomics techniques now 
allows testing, sequencing and selection at costs which are decreasing by the day (Richards et al. 2009). And with farmer innovators connected by internet and mobile phone, even in remote areas of Africa, the potential for radically new alliances for open source and low cost innovation, rooted in local systems and appropriate to local circumstances, open up. This is not a romantic reification of the traditional, but a radical shift in doing things which bypasses and subverts the conventional approaches, so easily captured by elite forms of expertise and business interests. This requires new thinking on innovation systems and the relationships between key players, linking farmers to other forms of skill and expertise based on new power relations and networks (Scoones and Thompson 2009; Hall 2009; Sumberg 2005). Supporting the Green Revolution in Africa would, under such a pathway, take on a different form, with different investments in different things in different places.

Releasing the idea of a Green Revolution for Africa from the technocratic grip of a narrowlydefined framing offers the opportunity for diverse framings. Gordon Conway talks of the 'Doubly Green Revolution', for example, one that combines conventional technologies for promoting production with those that assure sustainability (Conway 2007, 1997). Others argue for a low-external input Green Revolution that focuses on the application of agro-ecological principles, minimising environmental impacts, reducing agricultural pollutants and carbon footprints (Pretty et al. 2006). Others see seeds as part of biocultural diversity, a patrimony linked to histories and landscapes replete with deeper meanings and forms of cultural belonging (Haverkort and Rist 2007). Still others focus on the importance of locale, and the value of locallybased economies and 'food sovereignty' (Altieri 2009; Mulvany and Arce Moreira 2009; Pimbert 2009). All these visions of a Green Revolution have their validity and their place. But how can such diverse framings, with such diverse implications for alternative pathways, be debated in ways that allow a plurality of visions to flourish? This requires a more mature political debate about the future of agriculture - and within it seeds - in Africa, one that gets away from narrow technical-economic framings, but sees a Green Revolution as essentially a sociotechnical transformation, where technological elements (seeds being one) are combined with social, cultural and ecological dimensions in complex ways resulting in multiple configurations, suited to different settings.

In discussing alternative pathways, however, we do not want to set up an artificial dichotomy - good and bad, mainstream and alternative. As we have argued repeatedly, and as the contributions to this IDS Bulletin show, we need a more plural vision for Africa's new Green Revolution. In some settings, such as the well-endowed, high-potential, 'breadbasket' areas, the mainstream, rather narrow, vision may be highly appropriate, as it was in Asia's Green Revolution. While in others we need alternative perspectives and alternative pathways, or some hybrid combination.

Of course arguing for plural pathways and a diversity of responses has long been done. Indeed, concessions to alternatives and arguing that a 'one-size-fits-all' approach must be avoided is part of the wider rhetoric, with some calling for Green Revolutions (in the plural) or even a 'Rainbow Revolution' (Swaminathan 2004). But this does not, as the articles in this IDS Bulletin make clear, mean that in practice a plurality of diverse options are realised. Some pathways are more equal than others. And the reason for this is, as repeatedly highlighted, politics and interests that shape the way pathways are constructed, what gets funded and what gets ignored or undermined.

\section{Conclusions}

The discourse about the future of seed systems in Africa must stop treating Africa's Green Revolution agenda in strictly technocratic terms. A large part of the failure of previous attempts to kick start large-scale agricultural transformation on the continent was the result of ignoring the political economy of agrarian change and focusing narrowly on transferring the latest technologies through standard 'packages'. To repeat the errors of the past, when they have been so well documented and their consequences are still so clearly visible, is morally unacceptable. As contributors to this issue have argued so forcefully, yes, Africa does need new seeds and associated technological and market solutions to increase its farmers' productivity, enhance its economic growth and improve its people's food security. But this 'market led technology adoption' cannot be sustained on any large scale without addressing the politics of 
innovation - and with it, the interests, values and choices that drive agricultural technology research and development. For this reason, this agenda cannot, must not, be left only to the technocrats. It needs to be rescued as part of a legitimate, open, political debate about future options and pathways - about direction, distribution and diversity (STEPS 2010; Millstone et al. 2009).

One of the central lessons from the earlier Green Revolution in Asia is the need to respond actively to diverse geographical and social settings. For Africa, everything cannot be delivered as part of the 'maize model' - where germplasm responds to breeding efforts, hybrid varieties offer significant returns, the private sector is geared up and interested in breeding and multiplication, where agro-dealers are present and well trained, and where farm-level demand is widespread. This approach has certainly had its successes, and is central to the ambitions of major programmes such as AGRA, the Millennium Villages and GGIAR centres such as CIMMYT (Smale et al. 2011; Sanchez et al. 2009). It is also key to the business models of the likes of Monsanto, Pioneer and other multinational purveyors of seeds and agrochemicals. But the maize model has clear limits. As we have seen, for many crops, even other cereal crops (including teff, millet, to some extent sorghum), the model doesn't work. And for many women, poorer people, and those living away from markets they miss out.

If the Green Revolution is to be a broad-based, inclusive revolution, focused on poverty reduction, as well as yield increases and production growth, those who miss out from the mainstream must be a concern, for they represent the majority of Africa's population. Here the public sector becomes key. This may be an unfashionable focus in the welter of discussion about PPPs and new forms of African entrepreneurship, but in this field there are some basic public goods which are required if this wider ambition is to be realised. Even in the context of the mainstream Green Revolution narrative, the public sector is important: for upstream breeding work, the conservation of germplasm and crop biodiversity, as is well recognised by the likes of AGRA's Programme for Africa's Seed Systems (PASS). But, as we have discussed, public sector research and development capacity in Africa is in desperately poor shape. Decimated by a combination of structural adjustment 'reform' programmes, government neglect and a brain drain of expertise has left most national research organisations without well qualified staff and with few resources. Relying on the private sector, NGOs or the CGIAR to fill the gap is simply inadequate, and the rebuilding of effective national agricultural research systems, even if their mandates are refocused and narrowed, must remain central, whatever the pathways followed for Africa's Green Revolution.

To foster a wider diversity of pathways for the new Green Revolution in Africa, therefore, we need to encourage a more robust and inclusive debate about alternatives, with different visions implying different pathways which may be pursued in parallel or in combination. We need to diversify our narratives about the future, being more encompassing of different objectives and avoiding the danger of closing down and locking in to a particular technical-economic trajectory. In order to do this we need a more open political debate about the future, which challenges the vested interests which create singular, narrow visions. And through a more diverse vision of Africa's Green Revolution, and the role of seeds within it, we need to open up the innovation process, making use of new information technologies and networking opportunities to link high-end genomics with local adaptive research with farmers. These must go beyond highly individualised and privatised solutions to other group-based efforts, rooted in particular farming communities and contexts, and connected to public research and extension. One size must not fit all, especially in settings as diverse as those found across Africa. 


\section{Notes}

1 For details on these initiatives: Alliance for a Green Revolution in Africa - www.agraalliance.org/; Millennium Villages Project www.millenniumvillages.org/; Feed the Future - www.feedthefuture.gov/; Comprehensive Africa Agriculture Development Programme (CAADP) - http://www.nepad-caadp.net/ (accessed 5 May 2011).

2 Support for this issue of the IDS Bulletin was provided by the UK Department for International Development (DFID) as part of a grant to the Future Agricultures Consortium (FAC). Since 2005, FAC has built a dynamic partnership between leading African and UK institutions, developed a strong evidence base for policy influencing around a set of themes, including Science, Technology and Innovation, and engaged with agricultural policy processes at global, national and local levels. Further information can be found at: www.future-agricultures.org (accessed 15 April 2011).

\section{References}

Abdulai, A.; Barrett, C.B. and Hazell, P. (2004) Food Aid for Market Development in Sub-Saharan Africa, DSGD Discussion Paper 5, Development Strategy and Governance Division Washington DC: International Food Policy Research Institute

AGRA (2011) PASS Programme for Africa's Seed Systems: Supporting the Seed Value Chain in Africa, PASS Programme Brochure, Nairobi: Alliance for a Green Revolution in Africa

Alene, A.D.; Menkir, A.; Ajala S.O.; Badu-Apraku, B.; Alanrewaju A.S.; Manyong, V.M. and Ndiaye, A. (2009) 'The Economic and Poverty Impacts of Maize Research in West and Central Africa', Agricultural Economics 40: 535-50

Almekinders, C.J.M. and Louwaars, N.P. (2002) 'The Importance of the Farmers' Seed Systems in a Functional National Seed Sector', Journal of New Seeds 4.1: 15-33

Almekinders, C.J.M. and Louwaars, N.P. (1999) Farmers' Seed Production: New Approaches and Practices, London: Intermediate Technology Publications

Almekinders, C.J.M.; Louwaars, N.P. and Bruijn, G.H. (1994) 'Local Seed Systems and their Importance for an Improved Seed Supply in Developing Countries', Euphytica 78.3: 207-16

Altieri, M.A. (2009) 'Agroecology, Small Farms and Food Sovereignty', Monthly Review 61: 102-11
3 Public-private partnerships (PPPs) are increasingly viewed as an effective means of conducting advanced research, developing new technologies, and deploying new products for the benefit of small-scale farmers in developing countries. They involve joint planning and execution of R\&D activities with a view to accomplishing agreed-upon objectives while sharing the costs and benefits incurred in the process. To date, however, few partnerships in Africa are explicitly designed to facilitate joint innovation, an important justification for their use. Still fewer provide for effective management of the risks inherent in PPPs or sound analysis of their poverty-targeting strategies (cf. Spielman et al. 2009)

4 See Amanor (2009); Devereux, Scoones and Thompson (2009); and Havnevik et al. (2007) for critiques of the World Bank agenda as outlined in its 2008 World Development Report.

Brooks, S.; Thompson, J.; Odame, H.; Kibaara, B.; Nderitu, S.; Karin, F. and Millstone, E. (2009) Environmental Change and Maize Innovation in Kenya: Exploring Pathways In and Out of Maize, STEPS Working Paper 36, Brighton: STEPS Centre, University of Sussex Byerlee, D. and Eicher, C.K. (eds) (1997) Africa's Emerging Maize Revolution, Boulder CO: Lynne Rienner Publishers

Conway, G. (2007) 'A Doubly Green Revolution: Ecology and Food Production', in R.M. May and A.R. McLean (eds), Theoretical Ecology: Principles and Applications, Oxford: Oxford University Press

Conway, G. (1997) Doubly Green Revolution: Food for All in the Twenty-First Century, London: Penguin Books

Crawford, E.; Kelly, V.; Jayne, T. and Howard, J. (2003) 'Input Use and Market Development in Sub-Saharan Africa: An Overview', Food Policy 28.4: 277-92

Cromwell, E.; Friis-Hansen, E. and Turner, M. (1992) The Seed Sector in Developing Countries: A Framework for Performance Analysis, London: Overseas Development Institute

De Boef, W.; Amanor, K.; Wellard, K. and Bebbington, A. (1993) Cultivating Knowledge. Genetic Diversity, Farmer Experimentation and Crop Research, London: Intermediate Technology Publications 
De Vries, J. and Toenniessen, G.H. (2001)

Securing the Harvest: Biotechnology, Breeding and

Seed Systems for African Crops, Wallingford:

CABI Publishing

Denning, G.; Kabambe, P.; Sanchez, P.; Malik, A.; Flor, R.; et al. (2009) 'Input Subsidies to Improve Smallholder Maize Productivity in Malawi: Toward an African Green Revolution', PLoS Biology 7.1: e 1000023

Devereux, S.; Scoones, I. and Thompson, J. (2009) 'Critical Responses to the World Bank's World Development Report 2008: Agriculture for Development', Journal of Peasant Studies 36.2: 468-74

Djurfeldt, G.; Holmén, H.; Jirström, M. and Larsson, R. (2006) Addressing Food Crisis in Africa: What can Sub-Saharan Africa Learn from Asian Experiences in Addressing its Food Crisis?, Stockholm: Swedish International Development Cooperation Agency (Sida)

Ejeta, G. (2010) 'African Green Revolution Needn't Be a Mirage', Science 327: 831-2

Evenson, R.E. and Gollin, D. (2003) 'Assessing the Impact of the Green Revolution, 1960 to 2000', Science 300.5620: 758-62

FAO (2011) Current World Fertilizer Trends and Outlook to 2013, Rome: United Nations Food and Agriculture Organization

Funk, G.C. and Brown, M.E. (2009) 'Declining Global Per Capita Agricultural Production and Warming Oceans Threaten Food Security', Food Security 1: 271-89

Godfray, H.G.J.; Beddington, J.R.; Crute, I.R.; Haddad, L.; Lawrence, D.; Muir, J.F.; Pretty, J.; Robinson, S.; Thomas, S.M. and Toulmin, C. (2009) 'Food Security: The Challenge of Feeding 9 Billion People', Science 327: 812-18

GRAIN (2008) 'Seed Aid, Agribusiness and the Food Crisis. Editorial', Seedling, October: 2-9

Hall, A. (2009) 'Challenges to Strengthening Agricultural Innovation Systems: Where Do We Go From Here?', in I. Scoones and J. Thompson (eds), Farmer First Revisited: Innovation for Agricultural Research and Development, London: Practical Action

Haverkort, B. and Rist, S. (eds) (2007) Endogenous Development and Bio-cultural Diversity: The Interplay between Globalization, Worldviews and Locality, Leusden, The Netherlands: ETC/Compas and Bern, Switzerland: Centre for Development and Environment

Havnevik, K.; Bryceson, D.; Birgegård, L.; Matondi, P. and Beyene, A. (2007) African Agriculture and the World Bank: Development or
Impoverishment?, Uppsala: Nordic Africa Institute, www.nai.uu.se/publications/ electronic_publ/dialogue_havnevik.pdf (accessed 5 May 2011)

Hewitt de Alcántara, C. (ed) (1993) Real Markets: Social and Political Issues of Food Policy Reform, London: Frank Cass

Hunt, D. (2011) Green Revolutions in Africa, Programme Paper AFP 2011/01, London: Chatham House

IAASTD (International Assessment of Agricultural Knowledge, Science and Technology for Development) (2009) Agriculture at a Crossroads: A Synthesis of the Global and Sub-Global IAASTD Reports, Washington DC: Island Press

IAASTD (2008) Agriculture at the Crossroads: International Assessment of Agricultural Knowledge, Science and Technology for Development, Global Report, Washington DC: World Bank, www.agassessment.org/reports/IAASTD/EN/ Agriculture\%20at\%20a\%20Crossroads_Global \%20Report\%20(English).pdf (accessed 21 April 2011)

IFAD (2011) Rural Poverty Report 2011: New Realities, New Challenges: New Opportunities for Tomorrow's Generation, Rome: International Fund for Agricultural Development, www.ifad.org/rpr2011/report/e/ rpr2011.pdf (accessed 6 June 2010)

IFDC (2010) 'IFDC Announces New Project: COMESA Regional Agricultural Inputs Program (COMRAP)', IFDC Press Release (7 December 2010), Muscle Shoales AL: International Fertilizer Development Center Ingram, J.; Ericksen, P. and Liverman, D. (eds) (2010) Food Security and Global Environmental Change, London: Earthscan

InterAcademy Council (2004) Realizing the Promise and Potential of African Agriculture. Science and Technology Strategies for Improving Agricultural Productivity and Food Security in Africa, Amsterdam: InterAcademy Secretariat Jayne, T.; Mather, D. and Mghenyi, D. (2010) 'Principal Challenges Confronting Smallholder Agriculture in Sub-Saharan Africa', World Development 38.10: 1384-98

Juma, C. (2011) The New Harvest: Agricultural Innovation in Africa, New York: Oxford University Press USA

Keeley, J. and Scoones, I. (2003) Understanding Environmental Policy Processes: Cases from Africa, London: Earthscan

Langyintuo, A.; Mwangi, W.; Diallo, A.; MacRobert, J.; Dixon, J. and Bänziger, M. 
(2010) 'Challenges of the Maize Seed Industry in Eastern and Southern Africa: A Compelling Case for Private-Public Intervention to Promote Growth', Food Policy 35.4: 323-31

Langyintuo, A.S.; Mwangi, W.; Diallo, A.O.; MacRobert, J.; Dixon, J. and Bänziger, M. (2008) An Analysis of the Bottlenecks Affecting the Production and Deployment of Maize Seed in Eastern and Southern Africa, Harare: International Maize and Wheat Improvement Center

Leach, M.; Scoones, I. and Stirling, A. (2010) Dynamic Sustainabilities: Technology, Environment and Social Justice, Pathways to Sustainability Series, London: Earthscan

Lipton, M. with Longhurst, R. (1989) New Seeds and Poor People, London: Unwin Hyman

Livingston, G.; Schonberger, S. and Delaney, S. (2011) 'Sub-Saharan Africa: The State of Smallholders in Agriculture', paper presented at the IFAD Conference on New Directions for Smallholder Agriculture, 24-25 January 2011, Rome: International Fund for Agricultural Development

Longley, C.; Dominguez, C.; Saide, M.A. and Leonardo, W.J. (2002) 'Do Farmers Need Relief Seed: A Methodology for Assessing Seed Systems', Disasters 26.4: 343-55

Lynam, J. with Gilbert, E.; Elliot; H. and Blis, F. (2010) Evolving a Plant Breeding and Seed System in Sub-Saharan Africa in an Era of Donor Dependence, Rome: Global Initiative on Plant Breeding Capacity Building (GIPB), United Nations Food and Agriculture Organisation

McCann, J.C. (2005) Maize and Grace: Africa's Encounter with a New World Crop 1500-2000, Cambridge MA: Harvard University Press

McGuire, S.J. and Sperling, L. (2008)

'Leveraging Farmers' Strategies for Coping with Stress: Seed Aid in Ethiopia', Global Environmental Change 18: 679-88

Millstone, E. and Thompson, J. (2010) Governing Agri-Food Systems in the 21st Century, UK Foresight Global Food and Farming Futures Project Domain Paper 6, London: UK Government Office for Science

Millstone, E.; Thompson, J. and Brooks, S. (2009) Reforming the Global Food and Agriculture System, STEPS Working Paper 26, Brighton: STEPS Gentre, University of Sussex

Minot, N.; Smale, M.; Eicher, C.; Jayne, T.; Kling, J.; Horna, D. and Myers, R. (eds) (2007) Seed Development Programs in sub-Saharan Africa: A Review of Experiences, Washington DC: International Food Policy Research Institute
Miracle, M. (1966) Maize in Tropical Africa, Madison WI: The University of Wisconsin Press

Morris, M.L. (1998) Maize Seed Industries in Developing Countries, Boulder CO: Lynne Rienner Publishers

Morris, M.L.; Kelly, V.A.; Kopicki, R.J. and Byerlee, D. (2007) Fertilizer Use in African Agriculture Lessons Learned and Good Practice Guidelines, Washington DC: World Bank

Mosley, P. (2002) 'The African Green Revolution as a Pro-Poor Policy Instrument', Journal of International Development 14.6: 695-724

Mulvany, P. and Arce Moreira, M. (2009) 'Food Sovereignty: A Farmer-Led Policy Framework', in I. Scoones and J. Thompson (eds), Farmer First Revisited: Innovation for Agricultural Research and Development, London: Practical Action Publications

Otsuka, K. and Kajima, Y. (2011) 'Technology Policies for a Green Revolution and Agricultural Transformation in Africa', Journal of African Economics 19 (suppl 2): ii60-ii76

Pimbert, M. (2009) Towards Food Sovereignty: Reclaiming Autonomous Food Systems, London: International Institute for Environment and Development

Pretty, J.N.; Noble, A.D.; Bossio, D.; Dixon, J.; Hine, R.E.; Penning de Vries, F.W.T. and Morison, J.I.L. (2006) 'Resource-Conserving Agriculture Increases Yields in Developing Countries', Environmental Science and Technology 40.4: 1114-19

Remington, T.; Maroko, J.; Walsh, S.; Omanga, P. and Charles, E. (2002) 'Getting Off the Seedsand-tools Treadmill with CRS Seed Vouchers and Fairs', Disasters 26.4: 316-28

Richards, P. (1989) 'Farmers Also Experiment: A Neglected Intellectual Resource in African Science', Discovery and Innovation 1.1: 19-25

Richards, P. (1986) Coping with Hunger: Hazard and Experiment in an African Rice-Farming System, London: Allen \& Unwin

Richards, P.; de Bruin-Hoekzema, M.; Hughes, S.G.; Kudadjie-Freeman, G.; Kwame Offei, S.; Struik, P.C.; and Zannou, A. (2009) 'Seed Systems for African Food Security: Linking Molecular Genetic Analysis and Cultivator Knowledge in West Africa', International Journal of Technology Management 45.1/2:196-214

Rohrbach D.; Mashingaidze, A.B. and Mudhara, M. (2005) The Distribution of Relief Seed and Fertilizer in Zimbabwe, Lessons Derived from the 2003/04 Season, Bulawayo, Zimbabwe: The 
International Centre for Research in the Semi-Arid Tropics

Rohrbach, D.; Minde, I. and Howard, J. (2003)

'Looking Beyond National Boundaries:

Regional Harmonization of Seed Policies, Laws and Regulations', Food Policy 28.4: 277-92

Royal Society (2009) Reaping the Benefits: Science and the Sustainable Intensification of Global Agriculture, London: The Royal Society

Sanchez, P.A.; Denning, G.L. and Nziguheba, G. (2009) 'The African Green Revolution Moves Forward', Food Security 1.1: 37-44

Scoones, I. (2009) 'The Politics of Global Assessments: The Case of the International Assessment of Agricultural Knowledge, Science and Technology for Development (IAASTD)', Journal of Peasant Studies 36.3: 545-65

Scoones, I. (2005) 'Governing Technology Development: Challenges for Agricultural Research in Africa', IDS Bulletin 36.2: 109-14

Scoones, I. and Thompson, J. (eds) (2009) Farmer First Revisited: Innovation for Agricultural Research and Development, London: Practical Action Publications

Setimela, P.; Badu-Apraku, B. and Mwangi, W. (2009) 'Impediments to New Improved Maize Variety Testing and Release in Selected Countries in sub-Saharan Africa', African Crop Science Conference Proceedings 9: 447-50

Smale, M.; Byerlee, D. and Jayne, T. (2011) Maize Revolutions in Africa, Policy Research Working Paper 5659, Washington DC: World Bank

Sperling, L. (2008) When Disaster Strikes: A Guide to Assessing Seed System Security, Cali:

International Center for Tropical Agriculture

Sperling, L. and Longley, C. (2002) 'Editorial: Beyond Seeds and Tools: Effective Support to Farmers in Emergencies', Special Issue of Disasters 26.4: 283-7

Sperling, L. and McGuire, S.J. (2010) 'Persistent Myths about Emergency Food Aid', Food Policy 35.3: 195-201

Sperling, L.; Cooper, D. and Remington, T. (2008) 'Moving Towards More Effective Seed Aid', Journal of Development Studies 44: 586-612

Spielman, D.J.; Hartwich, F. and von Grebmer, K. (2009) 'Public-Private Partnerships and Developing-Country Agriculture', in I. Scoones and J. Thompson (eds), Farmer First Revisited: Innovation for Agricultural Research and Development, London: Practical Action Publications
Spielman, D.J.; Kelemwork, D. and Dawit Alemu (2011) Seed, Fertilizer, and Agricultural Extension in Ethiopia, ESSP II Working Paper 020, Washington DC: International Food Policy Research Institute and Addis Ababa: Ethiopia Strategy Support Program II http://essp.ifpri.info/files/2011/02/ESSP2_WP 20_SeedFertilizerAgrExtensionEthiopia.pdf (accessed 30 May 2011)

Sperling, L.; Remington, T.; Haugen, J.M. and Nagoda, S. (eds) (2004) Addressing Seed Security in Disaster Response: Linking Relief with Development, Cali: International Center for Tropical Agriculture

Sperling, L.; CIAT; CRS; World Vision; Care; AGRITEX and CIMMYT (2009) Seed System Security Assessment, Zimbabwe, Washington DC: United States Agency for International Development (USAID)

STEPS Centre (2010) Innovation, Sustainability, Development: A New Manifesto, Brighton: STEPS Centre, University of Sussex

Sumberg, J. (2005) 'Systems of Innovation Theory and the Changing Architecture of Agricultural Research In Africa', Food Policy 30: $21-41$

Swaminathan, M.S. (2004) 'Africa's Rainbow Revolution', TWAS Newsletter 3/4: 72-6

Tahirou, Abdoulaye; Diakalia Sanogo; Augustine Langyintuo; Simeon A. Bamire and Adetunji Olanrewaju (2009) Assessing the Constraints Affecting Production and Deployment of Maize Seed in DTMA Countries of West Africa, Ibadan: International Institute of Tropical Agriculture Thompson, J. and Scoones, I. (2009) 'Addressing the Dynamics of Agri-Food Systems: An Emerging Agenda for Social Science Research', Environmental Science and Policy 12: 386-97

Thompson, J.; Brooks, S.; Morgan, M; Millstone, E.; Odame, H.; Karin, F. and Adwera, A. (2010)Maize Security $\neq$ Food Security? Breaking the 'Lock in' to the Dominant Maize Pathway, STEPS Maize Briefing Paper 4, Brighton: STEPS Centre, University of Sussex

Thompson, J.; Brooks, S.; Morgan, M.; Millstone, E.; Odame, H.; Kibaara, B.; Nderitu, S.; Karin, F. and Adwera, A. (forthcoming) 'Environmental Change and Maize Innovation in Kenya: Seeking Resilience through Diversity'

Toenniessen, G.; Adesina, A. and Adesina, A. (2008) 'Building an Alliance for a Green Revolution in Africa', Annals of the New York Academy of Sciences 1136: 233-42 
Tripp, R. (2001) Seed Provision and Agricultural Development: The Institutions of Rural Charge, Oxford: James Currey

Tripp, R. (2000) Strategies for Seed System Development in Sub-Saharan Africa: A Study of Kenya, Malawi, Zambia, and Zimbabwe, ICRISAT Working Paper Series 2, Bulawayo, Zimbabwe: International Crops Research Institute for the Semi-Arid Tropics

Tripp, R. (1997) New Seed and Old Laws: Regulatory Reform and the Diversification of National Seed Systems, London: Intermediate Technology Publications

UK Foresight (2011) The Future of Food and Farming: Challenges and Choices for Global Sustainability, Final Project Report, London: UK Government Office for Science

United Nations (2004) World Population to 2300, Department of Economic and Social Affairs, Population Division, New York: United Nations Secretariat, www.un.org/esa/ population/publications/longrange2/ WorldPop2300final.pdf (accessed 21 April 2011) Walsh, S.; Bihizi, J-M.; Droeven, C.; Ngendahayo, B.; Ndaboroheye, B. and Sperling, L. (2004)
'Drought, Civil Strife, and Seed Vouchers and Fairs: The Role of the Trader in the Local Seed System', in L. Sperling, T. Remington, J.M. Haugen and S. Nagoda, (eds), Addressing Seed Security in Disaster Response: Linking Relief with Development, Cali: International Center for Tropical Agriculture

Wiggins, S (2009) Can the Smallholder Model Deliver Poverty Reduction and Food Security for a Rapidly

Growing Population in Africa?, FAC Working Paper 08, July, Brighton: Future Agricultures Consortium, www.future-agricultures.org/ Documents/Smallholder_S-Wiggins_Jul-09.pdf (accessed 21 April 2011)

Wiggins S. and Cromwell E. (1995) 'NGOs and Seed Provision to Smallholders in Developing Countries', World Development 23.3: 413-22

Wiggins, S.; Kirsten, J. and Liambi, L. (2010) 'The Future of Small Farms', World Development 38.10: 1341-8

World Bank (2007) World Development Report 2008 : Agriculture for Development, http://siteresources. worldbank.org/INTWDR2008/Resources/ WDR_00_book.pdf (accessed 21 April 2011) 